\title{
The Use of Game as a Strategy in Strengthening the Role of Physical Education Teachers to Improve the Manipulative Motion Skills of Elementary School Students
}

\author{
Feri Budi Setyawan ${ }^{1,2, *}$, Suharjana ${ }^{1}$, Ria Lumintuarso ${ }^{1}$ \\ ${ }^{1}$ Education Science, Postgraduate Program, Universitas Negeri Yogyakarta, Yogyakarta, Indonesia \\ ${ }^{2}$ Universitas Ahmad Dahlan, Yogyakarta, Indonesia
}

Received December 20, 2020; Revised May 6, 2021; Accepted May 16, 2021

\begin{abstract}
Cite This Paper in the following Citation Styles
(a): [1] Feri Budi Setyawan, Suharjana, Ria Lumintuarso, "The Use of Game as a Strategy in Strengthening the Role of Physical Education Teachers to Improve the Manipulative Motion Skills of Elementary School Students, "International Journal of Human Movement and Sports Sciences, Vol. 9, No. 4, pp. 661 - 667, 2021. DOI: 10.13189/saj.2021.090409.

(b): Feri Budi Setyawan, Suharjana, Ria Lumintuarso (2021). The Use of Game as a Strategy in Strengthening the Role of Physical Education Teachers to Improve the Manipulative Motion Skills of Elementary School Students. International Journal of Human Movement and Sports Sciences, 9(4), 661 - 667. DOI: 10.13189/saj.2021.090409.
\end{abstract}

Copyright $(2021$ by authors, all rights reserved. Authors agree that this article remains permanently open access under the terms of the Creative Commons Attribution License 4.0 International License

\begin{abstract}
The physical education teachers' active role also affects the low level of elementary school students' movement skills. The aim of the study was to find out the game strategies in strengthening physical education teachers' role to improve students' manipulative motion skills selection for upper-class elementary school students because of the ease of research and conformity of research purposes. The research was conducted at the public elementary school and it was located in the Ngemplak sub-district. The researcher developed the instrument relevant of manipulative game instrument to measure elementary school students' manipulative skills; the instrument was more focused on manipulative assessment (throwing, catching, and kicking). The study used an experimental quasi-design, consisting of 48 upper-class students divided into control groups and experimental groups. This study was conducted in five elementary schools in Ngemplak Subdistrict. Manipulative motion skills tests were given as pre-tests and post-test. To analyze the data, independent and paired t-tests were used at a .05 significance level. The results showed that the experimental group students had higher scores on both dependent variables than the control group. This suggests that manipulative play significantly improves the experimental group of manipulative motion skills
\end{abstract}

compared to students in the control group.

Keywords Games, Manipulative Motion, Elementary School Students

\section{Introduction}

Learning Outcomes are one of the benchmarks of successful learning objectives that have been implemented. Learning outcomes are measured based on learning objectives based on three areas, namely the cognitive realm of focus on knowledge, the affective realm, focusing on feelings and interests and the psychomotor realm focusing on motion skills and perception processes [1]. Learning outcomes relate to the learning objectives that are to be achieved in the learning process.

Physical education is believed to be able to develop three realms, it is supported that growth, development, and learning through physical activity will affect: (1) the Cognitive Realm: the ability to think (ask, be creative, and connect), the ability to understand (Perceptual Ability), awareness of movement and academic reinforcement; (2) The realm of Psychomotor: biological growth, physical 
fitness, as well as health, movement skills, and improved mobility skills; (3) Affective realm: pleasure, assumption of healthy physical activity, ability to express himself (self-realization), self-respect, and self-concept [2]. It is further that physical education is an integral part of the general educational process, which aims to develop students' physical, mental, emotional, and social good, with physical activity as its vehicle [3]. This physical activity can be used in an effort to maintain a healthy lifestyle in sports [4].

One of the formal institutions in the implementation of physical education is at the elementary school level. Physical education in elementary school provides opportunities for students to be engaged directly in various learning experiences through physical activity [5]. School is a key environment for physical activity; however, some teenagers are less active at that level of physical activity [6]. Around the age of 10-12 students enter formal operations, which are characterized by being able to handle hypothetical situations and their thought processes no longer depend solely on the immediate and real things [7]. The quality of physical education offered at the elementary school level is an essential for students to understand and develop their life skills [8]. One of the various skills that need to be trained is basic movement. The development of the movement is one part of the goal in the implementation of physical education itself.

Fundamental movement skills lay the foundations for students to participate in a variety of physical activities and sports [9]. The basic motion is one of the motions that needs to get attention for students in elementary school. Fundamental movement skills consist of locomotor skills, non-locomotor skills, and manipulative skills [10]. Physical education teachers must understand the stages in the development of the movement. The rate of basic motion development for each elementary school student varies depending on factors: gender, ancestry and growth [11]. Manipulative motion is usually described as movements that play with a particular object as its medium, or skills that involve a person's ability to use parts of his body to manipulate objects outside of him or her. This ability involves a lot of hands and feet for example: throwing, catching and kicking. The advantages of this manipulative skills are in accordance with the development of elementary school students, are not detrimental and are very easy to do with both male and female students. There must still be supervision of physical education teachers. Improving the competence of manipulative skills in physical education is the desired outcome of elementary school students [12].

Teachers as implements of education are required to have the intellectual ability, skills in managing the physical education process in order it runs well. Furthermore, teachers are required to have methodological skills in the role of education and implementation (Law of Teachers and Lecturers No. 14, 2005). The fact that the physical education process in the teacher's elementary school has not fully managed physical education in accordance with the goals of national education, even though the teacher factor has an important role in the development of student mobility skills. Using the game in physical education is more effective in improving students' manipulative motion skills.

The game-based physical education provides opportunities to develop the manipulative motion skills of students in elementary school [13]. This is in line with the concept of education in the tradition of pragmatism John Dewey sees education as a process of reorganization and reconstruction of individual experiences so as to increase individual efficiency in interaction with his environment [14]. Through interactive, engaging and creative game-based physical education will become a critical power development tool for students who collaborate with psychomotor abilities, especially manipulative movements of students. The game is a simple game that can be used for the physical education process in elementary school, this kind of activity can increase the motivation of students to take an active role in the movement [15]. The use of games in physical education can support the effectiveness of students' manipulative motion skills, as it is a top priority in improving the manipulative abilities of primary school students [16]. It is based on the fact that the student at that school age is the period of playing.

The research aims to develop the motion skills of elementary school students, especially manipulative skills of throwing, catching, and kicking. The use of games in the physical education process is expected to help physical education teachers in delivering abstract material, thus eliminating verbalistic impressions on students. A fun activity for students is playing, therefore physical education teachers, should use strategies in the form of games. Regarding to the condition in the field, physical education teachers need to present a game that can actively involve students so that there is motivation within the student to do moving. Through game activities, physical education teachers are expected to be able to improve the manipulative skills of elementary school students.

\section{Materials and Methods}

\subsection{Research Design}

This research is an experimental study of the results of the model of learning tool development. This study used a non-equivalent comparison-group design method. This design was one of the strong quasi-experimental research designs [17]. In this study, the researchers gave pre-test and post-test to students in the experimental and control groups. After the treatment, researchers compared the conditions before and after treatment in two groups. The 
dependent variables manipulative skills were thrown, catch and kick. The control group was given lessons as usual by teachers according to the school curriculum program, while the experimental group was given a game developed by researchers.

\subsection{Participants}

The subjects tried in this study were physical education teachers who had been teaching for more than 10 years and had certified primary school students over the age of 10-12. The research site was limited to, public elementary schools and it was located in Ngemplak District, Sleman Regency. These schools included of SD Negeri Randusari, SD Negeri Kejambon 2, SD Negeri Pencar 2 and SD Negeri Koroulon. The selection of elementary schools in Ngemplak sub-district because of the ease in research and the suitability of research objectives to test the game in improving the manipulative skills of elementary school students. The selection of the upper class based on considerations of thinking and moving skills can be useful in daily life. The study was conducted from February to April 2020.

\subsection{Control Group and Experimental Group}

At this stage of the study, the researcher used quasi-experimental design, pre-test, post control group design, and it consisted of 48 upper-class students who were divided into control groups and experimental groups. The study was conducted in five primary schools. Each 1 school was divided into two groups, namely experimental groups and control groups, with random sampling techniques. Quasi-experimental research with independent samples of the t-statistic design requires that both groups are equal. In this study, two groups of schools were equal because: (1) both groups came from the same school and applied physical education with the same facilities, (2) teachers who carried out physical education both had work experience over five years, (3) teachers who carried out physical education had been certified, both groups were from the upper class, (4) both groups were from the same class and (5) statistical test results using t-test against pre-test obtained $\mathrm{t}=0.071$ with six $0.944>0.05$. Thus, it can be concluded that Ho hypothesis indicated that there was no difference between the experimental and the control group so that it was accepted. Thus, both groups come from equal groups. In the test, the control group was treated simultaneously, but the game was different. The control group used a game commonly used in schools in the previous, experimental group using development games from researchers.

\subsection{Instruments}

\subsubsection{Manipulative Games}

The game's instruments were developed by researchers themselves. This manipulative game instrument is particularly relevant used to measure the manipulative skills of elementary school students as it is focused on this research on manipulative judgment (throwing, catching and kicking).

Table 1. Manipulative games

\begin{tabular}{|c|c|}
\hline Aspects & Indicators \\
\hline Material & $\begin{array}{r}\text { The suitability of the game with the basic } \\
\text { competencies that you want to achieve } \\
\text { The suitability of the game to the objectives to be } \\
\text { achieved } \\
\text { The suitability of the game with manipulative skills } \\
\text { Conformity with the characteristics of elementary } \\
\text { school students } \\
\text { Increase students' motivation } \\
\text { Construction }\end{array}$ \\
$\begin{array}{c}\text { Easy to play the game } \\
\text { Safe in playing the game } \\
\text { Cheap in getting the ingredients } \\
\text { The assessment is easy to do }\end{array}$ \\
\hline Language & $\begin{array}{c}\text { Clear game instructions } \\
\text { Match enhanced spelling }\end{array}$ \\
\hline
\end{tabular}

\subsubsection{Manipulative Motion Skills}

This instrument was developed by researchers with consideration of the developmental characteristics of elementary school students. This highly relevant skill instrument is used to measure the manipulative skills of primary school students as it is focused on this research on manipulative judgment (throwing, catching and kicking).

Table 2. Manipulative skills, observation

\begin{tabular}{|c|c|}
\hline Aspects & Indicators \\
\hline Throwing & $\begin{array}{l}\text { Students are able to throw at a specified distance } \\
\text { Students are able to throw on target } \\
\text { Students are able to maintain body position after } \\
\text { throwing }\end{array}$ \\
\hline Catching & $\begin{array}{l}\text { Students are able to capture at a specified distance } \\
\text { Students are able to catch on target } \\
\text { Students are able to maintain body position after } \\
\text { making a catch }\end{array}$ \\
\hline Kicking & $\begin{array}{l}\text { Students are able to kick with a specified distance } \\
\text { Students are able to kick on target } \\
\text { Students are able to maintain body position after } \\
\text { taking kicks }\end{array}$ \\
\hline
\end{tabular}

\subsection{Validity and Reliability Instruments}

Research instruments before being used to collect data and it was first tested for the validity and reliability tests. The validity category of each aspect assessed was determined based on categorization adapted from [18]. 
Table 3. Criteria for validity and rehabilitation of instruments

\begin{tabular}{|c|c|}
\hline Score Range (\%) & Category \\
\hline $85,01-100,00$ & $\begin{array}{l}\text { Very valid, can be used without the need for } \\
\text { revision }\end{array}$ \\
\hline $70,01-85,00$ & Valid, can be used but needs to be revised slightly \\
\hline $50,01-70,00$ & $\begin{array}{c}\text { Less valid, recommended not to use as it needs to } \\
\text { be revised largely }\end{array}$ \\
\hline $01,00-50,00$ & Invalid, not allowed to be used \\
\hline
\end{tabular}

The criteria used to decide that the instrument used have an adequate degree of validity if the average score is in the minimum category is quite valid. Furthermore, the instrument's reliability level test was conducted using Grinnell's Percentage of Agreement (PA) (1998) with the following formula:

Percent of Agreement (PA) $=\frac{\text { Agreement X } 100 \%}{\text { Disagreement }+ \text { Agreement }}$

The criteria of the instrument are said to be reliable when Coefficient $(\mathrm{PA}) \geq 0.70$. This is meant to ensure that the instruments used can actually measure what they are trying to measure and have a good time. The results of the instrument validity and reliability test, can be presented in table 4.

Table 4. Results of validity and reliability of instruments

\begin{tabular}{|c|c|c|c|c|}
\hline Instruments & Subject & M (\%) & $\begin{array}{l}\text { PA } \\
(\%) \\
\end{array}$ & Criteria \\
\hline $\begin{array}{c}\text { Manipulative } \\
\text { Games }\end{array}$ & $\begin{array}{c}\text { Game } \\
\text { Experts } \\
\text { Material } \\
\text { Experts }\end{array}$ & $\begin{array}{l}94.94 \\
93.71\end{array}$ & $\begin{array}{l}86.67 \\
87.78\end{array}$ & $\begin{array}{l}\text { Very } \\
\text { valid } \\
\text { Very } \\
\text { valid } \\
\end{array}$ \\
\hline $\begin{array}{c}\text { Manipulative } \\
\text { Motion }\end{array}$ & $\begin{array}{l}\text { Material } \\
\text { Experts }\end{array}$ & 97.23 & 91.67 & $\begin{array}{l}\text { Very } \\
\text { valid }\end{array}$ \\
\hline Response & $\begin{array}{l}\text { Game } \\
\text { Experts }\end{array}$ & $\begin{array}{l}85.00 \\
96.42\end{array}$ & $\begin{array}{l}70.00 \\
83.34\end{array}$ & $\begin{array}{l}\text { Very } \\
\text { valid } \\
\text { Very } \\
\text { valid }\end{array}$ \\
\hline
\end{tabular}

2.5.1. Manipulative Game Instrument Validity and Reliability Results

Based on experts in material of manipulative game validity. Material expert assessment sheet was obtained on average ( $M=93.71 \%)$ and the game's expert scoring sheet gained an average $(\mathrm{M}=94.94 \%)$. This indicates that the Highly Valid model assessment sheet instrument is used to retrieve data. Furthermore, based on the realization test using the percent of agreement for the material expert assessment sheet of $87.78 \%$, and the game expert assessment sheet of $86.67 \%$. This indicates that the instrument has a high level of restraint. Thus, it can be concluded that manipulative game validation sheet instruments are reliable and can be used to collect data.

\subsubsection{Manipulative Motion Instrument Validity and Reliability Results}

Based on experts in the field the validity of manipulative observation. The material expert assessment sheet was obtained on average $(M=97.23 \%)$. This indicates that manipulative motion observation instruments are very valid used to collect data. Furthermore, based on the realization test using the percentage of agreement obtained results $(\mathrm{M}=91.67 \%)$. This leads to the fact that the instrument has a high level of restraint. Thus, it can be concluded that manipulative observation sheet instruments are reliable and can be used to collect data.

\subsubsection{Results of Validity and Reliability of Response Instruments}

Based on game experts, the validity of the response sheet for teachers was obtained on average ( $M=96.42 \%)$ and the student sheet gets an average $(\mathrm{M}=85.00 \%)$. This indicates that the instrument of the response sheet is very valid to use to collect data. Furthermore, based on the realization test using the percentage of agreement obtained results $(M=83.34 \%)$ for teachers while for student responses gained results $(\mathrm{M}=70 \%)$. This is in line with the fact that the instrument has a high level of restraint. Thus, it can be concluded that the response sheet instrument is reliable and can be used to collect data. Overall, it can be concluded that the product is worth using.

\subsection{Data Analysis}

Kolmogorov-Smirnov was used to test the normality of pre- and post-test data. After fulfilling the assumptions of normality and homogeneity $(\mathrm{p}>.05)$, parametric statistics were used. The score of manipulative skills was analyzed using paired-samples t-test. In addition, the independent samples t-test was used to investigate whether there was a difference in scores on manipulative skills between the experimental and control groups. T-Tests were calculated in the SPSS version 20 program and 0.05 significance level was used.

\section{Results}

\subsection{Manipulative Game Development}

The main product of this research is manipulative games. Manipulative games are organized based on supporting components by paying attention to physical linkages, educational materials that exist in elementary schools. Manipulative games are teaching materials for upper class students (IV, V and VI) by looking at the core competencies and basic competencies of students in improving manipulative skills. The implementation of activities in this form is to play in the form of circuits that can be completed between teams or between groups. The rules of the game in a simple form have been applied so that students understand what to do and what not to do. 
The success of the game in this study is that all students are able to do activities in each activity (throwing the ball on target, picking up the ball and kicking the ball towards the goal). The game model also comes with an authentic assessment. Authentic assessments are seen based on his or her performance during the game by measuring manipulative skills. The success of manipulative game execution of this study is that students are able to perform activities in each activity (throwing with the ball on target, catching the ball and kicking the ball towards the goal).

\subsection{The Effect on Students' Manipulative Skills}

To answer the question of research, did the games used have a significant improvement in the manipulative skills of students? A paired samples t-test was employed. The results are presented in table 5 .

Table 5. The mean pre-test and post-test scores on manipulative skills

\begin{tabular}{|c|c|c|c|c|}
\hline \multirow{2}{*}{ Groups } & \multicolumn{2}{|c|}{ Mean scores } & \multirow{2}{*}{ Gain } & \multirow{2}{*}{ Criteria } \\
\cline { 2 - 3 } & Pre-test & Post test & & \\
\hline Experimental & 44.36 & 78.46 & .25 & Good \\
Control & 50.67 & 69.73 & .50 & Less \\
\hline
\end{tabular}

Table 5 shows that scores on pre-test manipulative skill score in experimental and control group students are the same. After treatment, both of them have improved. However, the experimental group score was higher than the control group. The score increase in the experimental group was 34.10 with a gain of 0,50 . It can be concluded that the manipulative skills of the experimental group students were higher than the control group after being given treatment.

To find out if there was a difference in manipulative motion skills among students in the control group and the experimental group, based on t-tests conducted.

Table 6. Independent t-test result on manipulative skills scores

\begin{tabular}{|c|c|c|c|c|c|}
\hline Groups & Groups & M & SD & df & Siq \\
\hline Pre-test & Experimental & 44.38 & 9.611 & 48 & .533 \\
& Control & 50.67 & 11.644 & & \\
Post-test & Experimental & 78.46 & 10.242 & & .000 \\
& Control & 69.73 & 11.966 & 48 & \\
\hline
\end{tabular}

Table 6 shows that experimental group students $(M=$ 44.38; $\mathrm{SD}=9.611)$ and control groups, students $(\mathrm{M}=$ $50.67 ; \mathrm{SD}=11.644)$ has almost the same score of manipulative motion skills. Based on Table 8, the p score on the posttest score is greater than 0.05 which means that there is no difference in manipulative motion skill scores between students who are taught to use the game before being given treatment $(p=.533)$. After treatment, there is a significant difference in manipulative basic motion skills of students in experimental groups and control groups $(\mathrm{p}=000)$. The scores for students in the experimental group $(\mathrm{M}=78.46 ; \mathrm{SD}=10,242)$ are higher than the students in the control group $(\mathrm{M}=69.73 ; \mathrm{SD}=10,242)$.

\section{Discussion and Conclusion}

\subsection{Discussion}

Physical education teachers have an important role to play in improving the manipulative skills of elementary school students. One of the strategies in improving the manipulative skills of students is by playing. The game is designed with complete material, construction and language aspects. For example, students easily understand, attract and motivate students to move. [19] asserted that the use of games in physical education can make it easier for teachers to deliver materials. [20] added that the game is one of the most exciting, popular and health-promoting activities of the 21 st century. It has been reinforced by [18] that fun physical activity can increase student engagement as well as maintain active participation during physical activity. Physical education through the game provides opportunities to improve students' manipulative skills without sacrificing learning goals.

The use of the game in physical education will be different from conventional physical education, Students' conventional physical education does not move much, while the games developed by researchers allow children to actively move. This is supported by previous research, by [21] which emphasized that the use of physical education involving a game approach should be more selective in planning activities. Although they have good intentions, this kind of approach requires the ability of physical education teachers to optimize it so that there are no mistakes in the physical education process. Reinforced by research conducted by [22] the importance of the game as an approach in physical education to create a student learning experience, including elements: social interaction, pleasure, challenges and motor skills. [23] asserted that students are more interested in physical education using the game in their activities than contingency. Interesting games can be used in physical education as a tool to improve students' manipulative skills. Thus, the game is an effective strategy in strengthening the role of physical education teachers to improve the manipulative skills of elementary school students.

After using the game, the manipulative skills of the elementary school students in the experimental group improved significantly, because the game teaches manipulative skills. In [11] emphasized that interesting games can attract students, motivate students to move and actively engage in the game. In addition, the world of elementary school students is played and often played in daily activities. This makes students more excited about physical activity. [24] confirmed there is a link between the implementation of pleasant physical education and student participation. This kind of situation should be designed by a physical education teacher so that students are interested in moving and can improve their manipulative skills. In this study to improve manipulative 
skills elementary school students can use the game.

In the control group after the experiment, the students did not show any significant changes in terms of manipulative skills. Development in student's psychomotor is needed, especially in its manipulative skills, this is in line with [25] that a new understanding of how to deal with the difficulties of manipulative skills. Thus, the improvement of skills is conventionally ineffective in physical education in elementary schools. For example, physical education is conventionally considered too boring, which sometimes it makes obstacles for elementary school students. In research conducted by [26] confirmed that difficulties in physical education so far include: low physical activity status, limited equipment, lack of time, number of students, loss of motivation and excessive daily workload. [27] emphasized that students with low skills are usually less confident and often unprepared to learn. Thus, the low manipulative mobility skills of students will have an effect on the success of students in physical education. The need for a well-planned method of physical education is to improve students' manipulative skills.

The findings in this study are supported by the research result of [28] physical education is different from other education because physical education focuses on a student's motor skills rather than his academic verbal, so the way to teach them is different. Mastery of basic skills is recognized as a contribution to the physical, cognitive and social development of students [29]. asserted that there is a strong link between basic skills and vigorous student activity in schools both independently and in groups [30]. Further strengthened by [31] providing a more complete understanding of the meaning of fundamental movement skills and their relationship to students' physical activity levels and the physical growth rate of students, as basic skills and physical activity are strongly related. Students prefer to spend time at school to play, it is important for physical education teachers to organize activities that appeal to their students. Providing assistance to physical education teachers in decision making as well as guidance in organizing physical education in schools that appeal to students so as to generate motivation to move [32]. The study illustrates the role of physical education teachers in improving students' motor skills, one of which is manipulative skills. Support needs to be provided to physical education teachers in primary schools, in professional individual development and given more opportunities.

\subsection{Conclusion}

In conclusion, this study shows that the use of games in physical education was very effectively used to improve the manipulative skills of elementary school students. Using games in physical education, students were better in improving manipulative skills than in conventional ways.
Students were more active in moving, enthusiastic, not afraid to try and unconsciously through the game impacting on improving their manipulative skills. Physical education teachers should be able to create creative games by integrating into students' manipulative skills. Thus, this research has shown that gaming is a strategy in strengthening the role of physical education teachers to improve the manipulative skills of primary school students.

Although this study was effective in improving manipulative skills, several limitations were found. First the game is limited to only a small fraction of manipulative skills such as throwing, catching and kicking. It is recommended to add other skills such as herding, hitting, rolling, bouncing, stopping and pushing. Both assessments conducted in this study did not arrive at long-term impact assessments, recommended for further research related to the impact on learning outcomes. A third needs to add a wider sample, for example, adding with a private school or comparing students in the countryside within urban areas.

\section{REFERENCES}

[1] L. W. Anderson and S. F. Bourke, Assessing affective characteristics in the schools. Routledge, 2000.

[2] Sukintaka, "Pembelajaran dan Masa Depan Teori Pendidikan Jasmani," Bandung, Nuansa, 2004.

[3] R. Bailey, "Sport, physical education and educational worth," Educ. Rev., vol. 70, no. 1, pp. 51-66, 2018.

[4] M. Gibson Taylor, E. Langenderfer Joseph, and I. Ustinova Ksenia, "Effects of breast motion on lower-body kinematics during running," Int. J. Hum. Mov. Sport. Sci., vol. 8, no. 2, pp. 51-56, 2020. DOI: 10.13189/saj.2020.080201.

[5] M. B. Jackson, "No Covaling Structure Analysis Title On Health-Related Indicators In Elderly People At Home With A Focus On Subjective Health," J. Control. Release, vol. 156, no. 1, pp. 315-322, 2011.

[6] E.-A. Abdelghaffar and B. Siham, "Perspectives of adolescents, parents, and teachers on barriers and facilitators of physical activity among school-age adolescents: a qualitative analysis," Environ. Health Prev. Med., vol. 24, no. 1, p. 21, 2019.

[7] B. R. Hergenhahn and M. H. Olson, "Theories of Learning (Teori Belajar Edisi ketujuh)," Terjem. oleh Tri Wibowo BS, 2008.

[8] C. Lu and A. De Lisio, "Specifics for Generalists: Teaching Elementary Physical Education," Int. Electron. J. Elem. Educ., vol. 1, no. 3, pp. 170-187, 2009.

[9] W. Chen, A. Hammond-Bennett, and A. Hypnar, "Examination of motor skill competency in students: Evidence-based physical education curriculum," $B M C$ Public Health, vol. 17, no. 1, pp. 1-8, 2017. 
[10] D. F. Stodden et al., "A developmental perspective on the role of motor skill competence in physical activity: An emergent relationship," Quest, vol. 60, no. 2, pp. 290-306, 2008.

[11] W. Chen, S. Mason, A. Hypnar, and A. Bennett, "Assessing motor skill competency in elementary school students: A three-year study," J. Sport. Sci. Med., vol. 15, no. 1, pp. 102$110,2016$.

[12] W. Chen, W. Zhu, S. Mason, A. Hammond-Bennett, and A. Colombo-Dougovito, "Effectiveness of quality physical education in improving students' manipulative skill competency," J. Sport Heal. Sci., vol. 5, no. 2, pp. 231-238, 2016.

[13] G. L. Gutek, "Philosophical Alternatives in Education. Ohio: Charles E." Merrill Publishing Company, 1974.

[14]E. S. Katartzi and S. P. Vlachopoulos, "Motivating children with developmental coordination disorder in school physical education: The self-determination theory approach," Res. Dev. Disabil., vol. 32, no. 6, pp. 2674-2682, 2011.

[15] T. Pritchard, A. Hawkins, R. Wiegand, and J. N. Metzler, "Effects of two instructional approaches on skill development, knowledge, and game performance," Meas. Phys. Educ. Exerc. Sci., vol. 12, no. 4, pp. 219-236, 2008.

[16] L. B. Christensen, B. Johnson, L. A. Turner, and L. B. Christensen, "Research methods, design, and analysis," 2011.

[17] L. H. Eddy et al., "The validity and reliability of observational assessment tools available to measure fundamental movement skills in school-age children: A systematic review," PLoS One, vol. 15, no. 8, p. e0237919, 2020.

[18]G. J. Forrest, P. Webb, and P. Pearson, "Games for understanding in pre service teacher education: a'game for outcome'approach for enhanced understanding of games," 2007.

[19] A. E. Staiano and S. L. Calvert, "Exergames for Physical Education Courses: Physical, Social, and Cognitive Benefits," Child Dev. Perspect., vol. 5, no. 2, pp. 93-98, 2011.

[20]A. MacPhail, T. Gorely, D. Kirk, and G. Kinchin, "Children's experiences of fun and enjoyment during a season of sport education," Res. Q. Exerc. Sport, vol. 79, no. 3, pp. 344-355, 2008.

[21]A. Casey and A. MacPhail, "Adopting a models-based approach to teaching physical education," Phys. Educ. Sport
Pedagog., vol. 23, no. 3, pp. 294-310, 2018.

[22] S. Beni, T. Fletcher, and D. Ní Chróinín, "Meaningful Experiences in Physical Education and Youth Sport: A Review of the Literature," Quest, vol. 69, no. 3, pp. 291-312, 2017.

[23] E. Singleton, "From command to constructivism: Canadian secondary school physical education curriculum and teaching games for understanding," Curric. Inq., vol. 39, no. 2, pp. 321-342, 2009

[24] A. MacPhail, T. Gorely, D. Kirk, and G. Kinchin, "Exploring the meaning of fun in physical education through Sport Education," Res. Q. Exerc. Sport, vol. 79, no. 13, pp. 344 356, 2008.

[25] R. Medcalf, J. Marshall, and C. Rhoden, "Exploring the relationship between physical education and enhancing behaviour in pupils with emotional behavioural difficulties," Support Learn., vol. 21, no. 4, pp. 169-174, 2006.

[26] L. Trinkūnienè and L. Kardelienè, "Occupational Difficulties At Work of Physical Education Teachers," Balt. J. Sport Heal. Sci., vol. 1, no. 88, pp. 88-96, 2013.

[27] L. E. Robinson, "The relationship between perceived physical competence and fundamental motor skills in preschool children," Child. Care. Health Dev., vol. 37, no. 4, pp. 589-596, 2011.

[28]E. Shoval, I. Erlich, and N. Fejgin, "Mapping and interpreting novice physical education teachers' self-perceptions of strengths and difficulties," Phys. Educ. Sport Pedagog., vol. 15, no. 1, pp. 85-101, 2010.

[29] D. R. Lubans, P. J. Morgan, D. P. Cliff, L. M. Barnett, and A. D. Okely, "Fundamental movement skills in children and adolescents: Review of associated health benefits," Sport. Med., vol. 40, no. 12, pp. 1019-1035, 2010.

[30] A. Fisher et al., "Fundamental movement skills and habitual physical activity in young children," Med. Sci. Sports Exerc., vol. 37 , no. 4, pp. 684-688, 2005.

[31] S. P. Kalaja, T. T. Jaakkola, J. O. Liukkonen, and N. Digelidis, "Development of junior high school students' fundamental movement skills and physical activity in a naturalistic physical education setting," Phys. Educ. Sport Pedagog., vol. 17, no. 4, pp. 411-428, 2012.

[32] B. Holfelder and N. Schott, "Relationship of fundamental movement skills and physical activity in children and adolescents: A systematic review," Psychol. Sport Exerc., vol. 15 , no. 4, pp. 382-391, 2014. 